\title{
Essential oils obtained by flash vacuum-expansion of peels from lemon, sweet orange, mandarin and grapefruit
}

Pierre Brat, Didier Ollé, Anne-Laure Gancel, Max Reynes, Jean-Marc Brillouet ${ }^{\star}$

Centre de Coopération agronomique pour

le développement (Cirad), Département Flhor,

TA 50 / PS4,

boulevard de La Lironde, 34398 Montpellier Cedex 5, France

brillouet@cirad.fr internationale en recherche

\section{Essential oils obtained by flash vacuum-expansion of peels from lemon, sweet orange, mandarin and grapefruit.}

Abstract - Introduction. Essential oils represent an increasing economic importance in the citrus by-product industry. Flash vacuum-expansion, a process leading to the disintegration of plant tissues, was applied to the recovery of essential oils from fruits of four Citrus species. Materials and methods. The flash vacuum-expansion process (steam-heating, then rapid introduction into a vessel under vacuum) was applied to peels of lemon, sweet orange, mandarin and grapefruit. Essential oils were recovered with a condenser, then separated by centrifugation. Oil volatile compounds were separated and identified by coupled capillary gas liquid chromatography/mass spectrometry. Results and discussion. Peel essential oil yields were $(2.41,1.43,0.64$ and 0.73$) \mathrm{kg} \times \mathrm{t}^{-1}$ of fruit for lemon, sweet orange, mandarin and grapefruit, respectively. Oils were enriched in limonene and other monoterpenes, while relative concentrations of monoterpene alcohols (linalool, $\alpha$-terpineol, $\beta$-citronellol, nerol, geraniol) and aldehydes (neral, geranial) were lower in comparison with the volatile compounds of native peels. Conclusion. The flash vacuum-expansion process allowed production of citrus peel essential oils with yields comparable to the Food Machinery Corporation (F.M.C.) process. Oils were enriched in monoterpene hydrocarbons and correlatively impoverished in oxygenated volatile constituents.

citrus / agroindustrial sector / methods / extraction / essential oils / plant extracts / peel

\section{Huiles essentielles obtenues par flash détente sous vide d'écorces de citrons, oranges, mandarines et pomelos.}

Résumé - Introduction. Les huiles essentielles ont une importance économique croissante dans l'industrie des sous-produits d'agrumes. Le procédé de flash détente sous vide, un processus provoquant la désintégration de tissus végétaux, a été appliqué à l'extraction d'huiles essentielles des fruits de quatre espèces de Citrus. Matériels et méthodes. Le procédé de flash détente (chauffage à la vapeur, puis introduction rapide dans un récipient sous vide) a été appliqué à des écorces de citrons, oranges, mandarines et pomelos. Les huiles essentielles ont été récupérées à l'aide d'un condenseur, puis séparées par centrifugation. Les composés volatils ont été séparés et identifiés par chromatographie en phase gazeuse sur colonne capillaire couplée à la spectrométrie de masse. Résultats et discussion. Les rendements en huiles essentielles des écorces ont été respectivement de $(2,41,1,43,0,64$ et 0,73$) \mathrm{kg} \times \mathrm{t}^{-1}$ de fruits pour le citron, l'orange, la mandarine et le pomelo. Les huiles ont été enrichies en limonène et autres monoterpènes, alors que les concentrations relatives en alcools monoterpéniques (linalol, $\alpha$-terpinéol, $\beta$-citronellol, nérol, géraniol) et en aldéhydes (néral, géranial) ont été abaissées par rapport aux composés volatils des écorces brutes. Conclusion. Le procédé de flash détente sous vide a permis d'extraire des huiles essentielles de l'écorce d'agrumes avec des rendements comparables à ceux obtenus par le procédé de la Food Machinery Corporation (F.M.C.). Les huiles ont été enrichies en monoterpènes et corrélativement appauvries en composants volatils oxygénés.

Fruits, 2001, vol. 56, p. 395-40 (C) 2001 Cirad/EDP Sciences All rights reserved

Resumen Español, p. 402 agrumes / secteur agro-industriel / méthodes / extraction / huiles essentielles / ex traits d’origine végétale / écorce 


\section{Introduction}

Aside from single strength and concentrated juices, massive amounts of peels are recovered from the citrus juice industry. Valorisation of these by-products is achieved in diverse manners: production of pectins, feed for livestock, recovery of essential oils, waxes and flavonoids, and also minor uses such as lemon (Citrus lemon L) and citron peel (Citrus medica L.) candying, bitter orange peel (Citrus aurantium L.) marmalade and liquors [1-3]. Citrus essential oils are of major concern to the food (soft drinks), detergent, cosmetic and perfume industries. Most of the citrus essential oils are nowadays recovered simultaneously with the fruitjuice extraction as cold-pressed oils by the Food Machinery Corporation (F.M.C.) process $[4,5]$. Yields of essential oils depend on the Citrus species, cultivar, area and period of production; typical yields with the F.M.C. procedure are: $3 \mathrm{~kg} \times \mathrm{t}^{-1}$ of lemons, $1.5 \mathrm{~kg} \times \mathrm{t}^{-1}$ of sweet oranges and $1 \mathrm{~kg} \times \mathrm{t}^{-1}$ of grapefruits (Riverbend ${ }^{1}$, pers. commun.).

In the flash vacuum-expansion process, plant materials are first steam-heated for (5 to 10) $\mathrm{min}$ at (70 to 90 ) ${ }^{\circ} \mathrm{C}$ before being instantly introduced into a vacuum chamber at ( 2 to 5 ) $\mathrm{kPa}$. This process has occasionally been used for a decade in the wine making industry [6]. When heated grapes enter the vacuum chamber, the grape skin disintegrates due to the instant evaporation of $10 \%$ of water and volatile components, thus facilitating the diffusion of skin anthocyanins. After fermentation, red wines from vacuum-expanded grapes are more coloured than those from traditionally processed grapes. Thus, this process can be viewed as an extraction process [7] which could serve for the recovery of volatile compounds from agro-industry wastes.

Since citrus peel essential oils are contained in balloon-shaped vesicles located in the flavedo of citrus peel, we thought that the flash vacuum-expansion process would lead to rupture of the vesicle walls, thus releasing oils which would be recoverable through a condenser. We tested this process on lemon, sweet orange, mandarin and grapefruit peels.

\section{Materials and methods}

\subsection{Fruits}

Sound mature lemons [Citrus limon (L.) Burm, cv. Primafiori], sweet oranges [Citrus sinensis (L.) Osb, cv. Naveline], mandarins [Citrus reticulata Blanco, cv. Villalate] and grapefruits [Citrus paradisi Macfayden, cv. Ruby Red] were obtained from a local market, stored in cold conditions $\left(4^{\circ} \mathrm{C}\right)$ and processed a week after. Peels were obtained by gently hand-pressing halved fruits in a Santos ${ }^{\circledR}$ juicer.

\subsection{Solvents and chemicals}

The solvents (n-pentane, dichloromethane) were of analytical grade. Reference compounds, if available, and n-alkanes $\left(\mathrm{C}_{5}-\mathrm{C}_{22}\right)$ standards were from Aldrich Chimie (SaintQuentin Fallavier, France).

\subsection{Flash vacuum-expansion experiment}

Peels $(100 \mathrm{~kg})$ were introduced through a loading funnel into a horizontal stainless steel steam-heating chamber (figure 1) $(\mathrm{L}=230 \mathrm{~cm}, \mathrm{l}=40 \mathrm{~cm}, \mathrm{~h}=50 \mathrm{~cm}$ ) equipped at its bottom with a rotating twin screw $(\mathrm{L}=220 \mathrm{~cm}, \varnothing=15 \mathrm{~cm})$ for both conveying and steam-heating the peels at normal pressure through steam injection holes (figure 2). Peel exudates and condensed steam were collected through pipes at the heating chamber bottom and discarded. After having passed through the steamheating chamber $(7 \mathrm{~min})$, heated peels $\left(85^{\circ} \mathrm{C}\right.$ to $90{ }^{\circ} \mathrm{C}$ ) were introduced through an airtight feeding pump into a large vacuum vessel (figure 3$)(\mathrm{r}=30 \mathrm{~cm}, \mathrm{~h}=150 \mathrm{~cm}$, $\mathrm{v}=424 \mathrm{~L})$ where a vacuum $(3 \mathrm{kPa})$ was generated by a vacuum pump cooled by a closed cooling water circuit [8]. Instantly evaporated aromatic liquors (water phase) and essential oils were collected after passage into a condenser $(\mathrm{h}=210 \mathrm{~cm}$, $\varnothing=23 \mathrm{~cm})$; oils were then recovered by centrifugation (9000 g, $5 \mathrm{~min}$ ) and kept in the cold $\left(-20^{\circ} \mathrm{C}\right)$ under argon. 


\subsection{Hydrodistillation}

Extraction yields of essential oils by flash vacuum expansion (table I) were determined by submitting native and vacuumexpanded peels to hydrodistillation. Peels $(200 \mathrm{~g})$ were added to distilled water (500 mL), thoroughly mixed at high speed for $3 \mathrm{~min}$ in a Waring blender (Waring, USA), and submitted for $3 \mathrm{~h}$ to hydrodistillation in a Clevenger-type apparatus.

\subsection{Extraction of volatile compounds}

Aliquots $(100 \mathrm{~g})$ of native and vacuumexpanded peels were cryomilled in liquid nitrogen with a Dangoumill 300 freezermill (Prolabo, Paris, France) for 3 min (top impact frequency). An aliquot of the finely pulverised peel $(0.5 \mathrm{~g})$ was stirred into $30 \mathrm{~mL}$ of azeotropic (pentane/dichloromethane, 2:1) mixture. Phase separation was achieved by centrifugation at $9000 \mathrm{~g}$ for $5 \mathrm{~min}$. The upper organic phase was recovered, dried over anhydrous sodium sulphate and finally concentrated at $37^{\circ} \mathrm{C}$ with a $25 \mathrm{~cm}$ Vigreux distillation column to a volume of $2 \mathrm{~mL}$. Prior to GC and GC-MS analysis, solvent extracts were diluted ( $1 / 10$, $\mathrm{v} / \mathrm{v}$ ) in the above azeotropic mixture.

\subsection{GC analysis}

A Varian 3380 gas chromatograph was used with a flame ionisation detector (FID), an on-column injector, a DB-Wax (column A, $\mathrm{J} \& \mathrm{~W}$ Scientific, Folsom, CA, USA) fused silica capillary column $(60 \mathrm{~m} \times 0.32 \mathrm{~mm}$ i.d. $\times 0.25 \mu \mathrm{m}$ film) or a DB-1 (column B, J \& W Scientific, Folsom, CA, USA) fused silica capillary column $(30 \mathrm{~m} \times 0.32 \mathrm{~mm}$ i.d. $\times$ $0.25 \mu \mathrm{m}$ film). Oven temperature was increased from $40{ }^{\circ} \mathrm{C}$ to $245^{\circ} \mathrm{C}$ at a rate of $3^{\circ} \mathrm{C} \times \mathrm{min}^{-1}$ where it was held for $20 \mathrm{~min}$. Injector temperature was raised from $20^{\circ} \mathrm{C}$ to $245{ }^{\circ} \mathrm{C}$ at $180{ }^{\circ} \mathrm{C} \times \mathrm{min}^{-1}$ where it was held for $90 \mathrm{~min}$. Detector temperature was $245^{\circ} \mathrm{C}$. Hydrogen was the carrier gas at $2.0 \mathrm{~mL} \times \mathrm{min}^{-1}$. Injected volumes were $2 \mu \mathrm{L}$ of concentrated extract. Response factors were taken as 1.0 for all compounds, except for limonene (1.3), with reference to $\mathrm{n}$-hexanol as internal standard. Linear retention indices were calculated with reference to $\mathrm{n}$-alkanes $\left(\mathrm{C}_{5}-\mathrm{C}_{22}\right)$. Concentrations are given as the average of triplicate analyses.

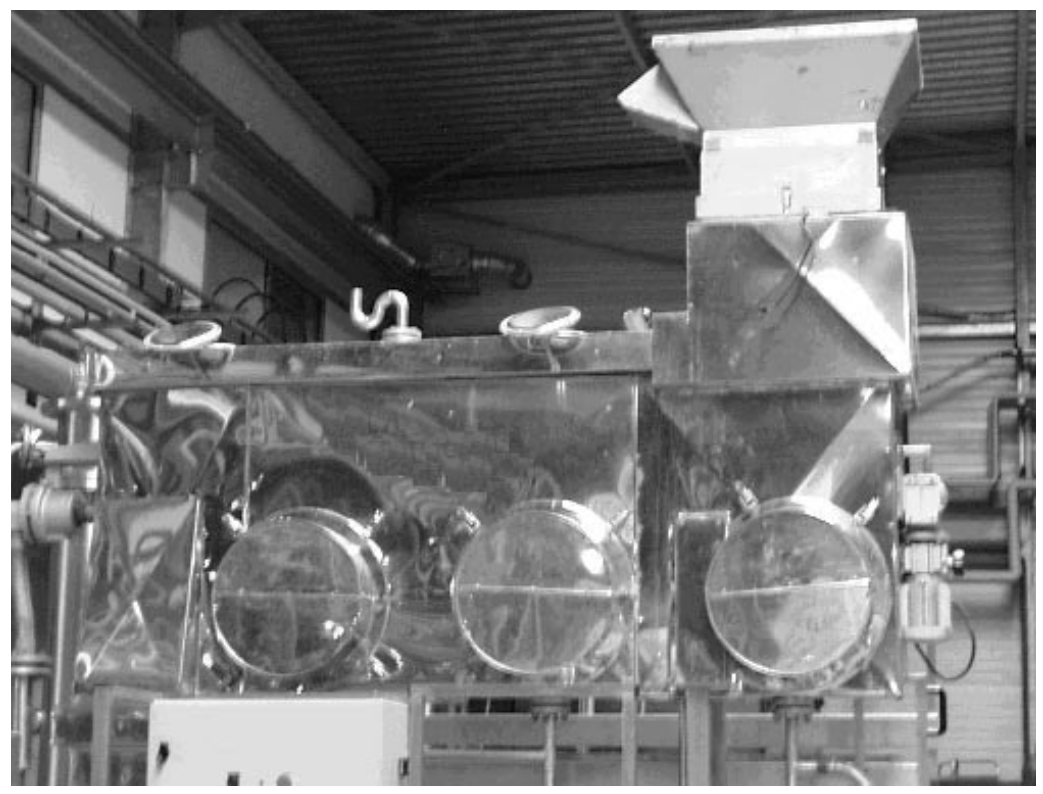

Figure 1.

Steam-heating chamber of the flash vacuum-expansion process (with the permission of FABBRI SA, 84320 Entraigues, France).

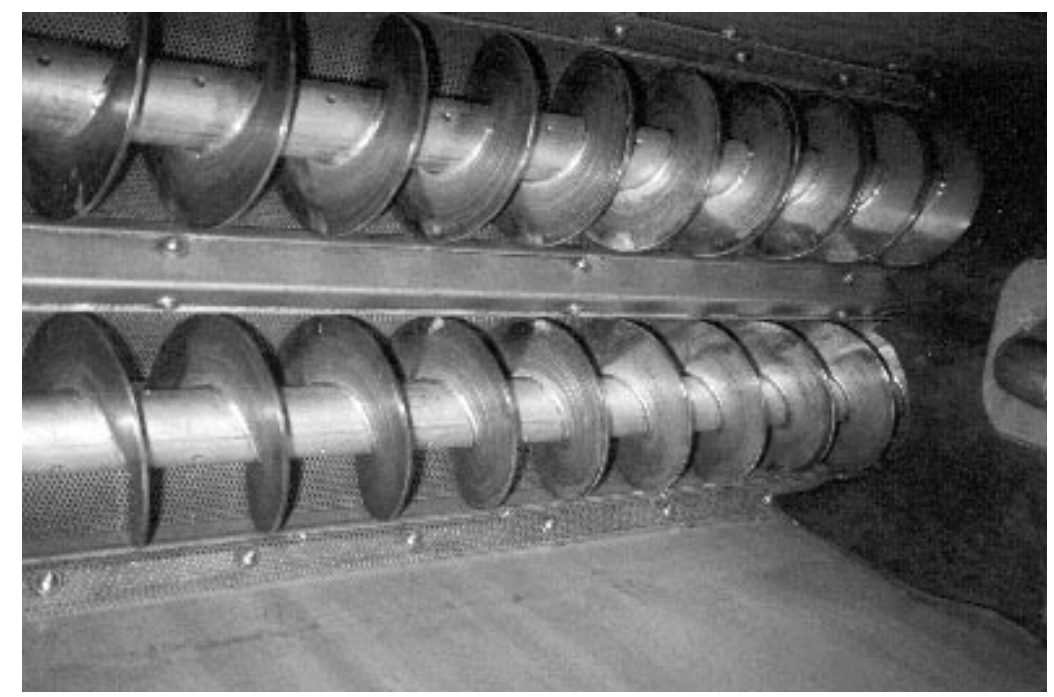

Figure 2.

Steam-heating injection screw (with the permission of FABBRI SA, 84320 Entraigues, France). 
Figure 3.

Vacuum chamber and oil recovery system (with the permission of FABBRI SA, 84320 Entraigues, France).

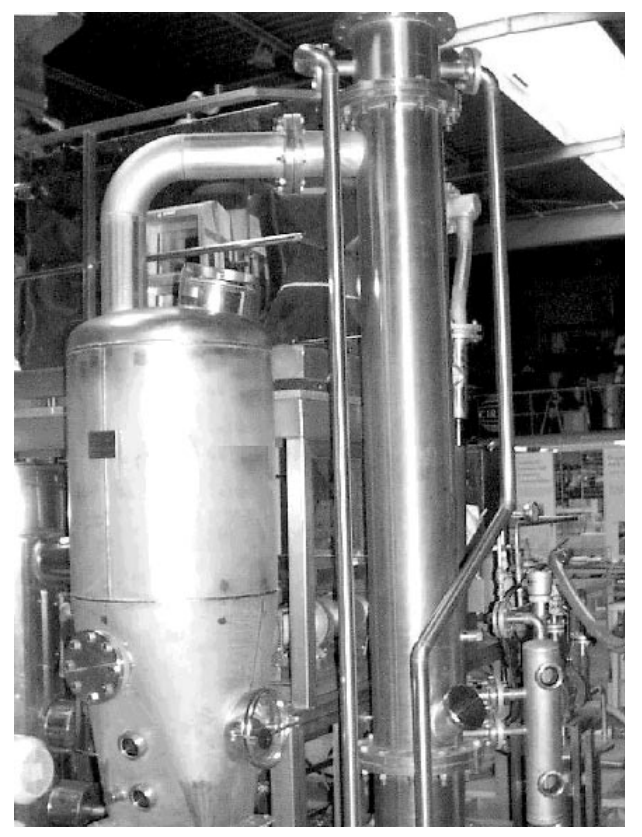

\subsection{GC-MS analysis}

A Varian 3300 gas chromatograph coupled to a Fisons Trio-1000 quadrupole mass spectrometer with an electron ionisation mode (EI) generated at $70 \mathrm{eV}$ was used. The ion source temperature was $200{ }^{\circ} \mathrm{C}$ and the filament emission current was $1 \mathrm{~mA}$. The same columns as above were used for separation. Oven temperature was increased from $40^{\circ} \mathrm{C}$ to $220^{\circ} \mathrm{C}$ at a rate of $3{ }^{\circ} \mathrm{C} \times \mathrm{min}^{-1}$ where it was held for $20 \mathrm{~min}$. The injector was heated from $20{ }^{\circ} \mathrm{C}$ to $245{ }^{\circ} \mathrm{C}$ at $180{ }^{\circ} \mathrm{C} \times$ $\mathrm{min}^{-1}$. Detector temperature was $245^{\circ} \mathrm{C}$. Helium was the carrier gas at $1.1 \mathrm{~mL} \times \mathrm{min}^{-1}$. Electron impact mass spectra were recorded in the (40 to 600) amu (atomic mass unit) range at $1 \mathrm{~s}$ interval. Injected volumes were $1 \mu \mathrm{L}$ of concentrated extract.

Compounds were identified on the basis of linear retention indices on both columns (DB-Wax and DB-1) and EI mass spectra (Electronic impact mass spectra library, Wiley, $275 \mathrm{~L}$ and [9]) from the literature or from authentic standard compounds.

\section{Results and discussion}

\subsection{Extraction of essential oils by flash vacuum-expansion}

The essential oil contents of native and vacuum-expanded peels were determined using hydrodistillation and the difference was compared to the oil weight actually recovered in the condensor after vacuumexpansion (table I).

Amounts of peel essential oils recovered by vacuum-expansion process ranged from $2.41 \mathrm{~kg} \times \mathrm{t}^{-1}$ of fruit for lemon to $0.64 \mathrm{~kg} \times \mathrm{t}^{-1}$ for mandarin (table I). Considering efficient

Table I.

Theoretical and efficient yields in citrus peel essential oils obtained by flash vacuum-expansion ( $\mathrm{kg}$ essential oils $\times \mathrm{t}^{-1}$ fruits).

\begin{tabular}{lcccc} 
Origin of the essential oils & Lemon & Sweet orange & Mandarin & Grapefruit \\
\hline Native peels & & & & \\
Vacuum-expanded peels $^{2}$ & 5.50 & 4.96 & 1.91 & 2.70 \\
Theoretical recoverable amount $^{3}$ & 1.89 & 3.09 & 0.98 & 1.85 \\
Vacuum-expanded essential oil $^{4}$ & 3.62 & 1.87 & 0.93 & 0.85 \\
Yield $^{5}$ (\%) & 2.41 & 1.43 & 0.64 & 0.73 \\
& 44 & 29 & 33 & 27 \\
${ }^{1}$ Maximum recoverable oil amount (obtained by hydrodistillation). \\
${ }^{2}$ Residual oil in processed peels (obtained by hydrodistillation). \\
${ }^{3}$ Difference between native and vacuum-expanded essential oil peel contents obtained by hydrodis- \\
tillation. \\
${ }^{4}$ Amount actually recovered from the condenser. \\
${ }^{5}$ Yield = [(amount actually recovered / maximum recoverable oil amount) $\left.\times 100\right]$.
\end{tabular}


yields calculated as the ratio between actually recovered essential oils by flash vaccuum-expansion versus the theoretical recoverable amount, they ranged from $67 \%$ for lemon to $86 \%$ for grapefruit, showing the good efficiency of the condensing system. Overall extraction yield (= oil amount actually recovered / oil amount in native peels) varies from $27 \%$ of oils effectively contained in the grapefruit peels to $44 \%$ for lemon. These yields were comparable to the yields attainable by the F.M.C. process, (3, 1.5 and 1) $\mathrm{kg} \times \mathrm{t}^{-1}$ for lemons, sweet oranges and grapefruits, respectively (Riverbend ${ }^{1}$, pers. commun.).

\subsection{Composition of citrus essential oils}

Quantitative analysis of volatile compounds were firstly performed on native peels and peels exiting the steam-heating chamber: similar amounts and relative distributions were observed in both cases showing that oils were neither lost, nor damaged by the first steam-heating step.

With regard to the native peel volatile compounds, the four citrus oils obtained by vacuum-expansion were relatively enriched in limonene, the major citrus peel monoterpene hydrocarbon [5], especially in the case of lemon (table II). The same trend was observed for $\beta$-pinene while other monoterpenes remained more or less constant. The behaviour of the sesquiterpenes [cis- and trans- $\alpha$-bergamotene, $\beta$-caryophyllene, $\alpha$-humulene, (Z)- $\beta$-farnesene, valencene, $\beta$-bisabolene, and $\delta$-cadinene] was variable, either remaining constant, or decreasing after vacuum-expansion. This relative increase in limonene content is accompanied by a relative decrease in oxygenated compounds.

The relative distribution of volatile components obtained from lemon native peels lay in the range of those reported for Italian lemon peel oils [5] with $\sim 65 \%$ limonene, $\sim 9 \% \beta$-pinene, $\sim 8 \% \gamma$-terpinene, $\sim 1.5 \%$ $\beta$-myrcene and $\sim 1.5 \% \alpha$-pinene. Monoterpene aldehydes, neral and geranial, were present at high levels, $\sim 1 \%$ and $\sim 3 \%$, respectively. It must be mentioned that two monoterpene alcohols, nerol and geraniol, were present in very high relative concentrations as compared to Mediterranean or American oils [5, 10]. After vacuum expansion, oil was enriched in monoterpene hydrocarbons (limonene, $\beta$-pinene, $\gamma$-terpinene, sabinene, $\alpha$-pinene and $\beta$-myrcene). Monoterpene alcohols (linalool, $\alpha$-terpineol, $\beta$-citronellol, nerol and geraniol) and their acetates were drastically reduced while concentrations of monoterpene aldehydes (citronellal, neral and geranial) were divided by a factor of 1.5 to 2 (table II). Aliphatic aldehydes (hexanal, octanal, nonanal and decanal) were not affected.

The relative distribution of volatile components obtained from sweet orange native peels exhibited a very high proportion of mono- and sesquiterpene hydrocarbons $(>98 \%)$ in agreement with previously reported compositions [10]. Apart from valencene which was found in high relative concentration, other compounds (monoterpene and sesquiterpene alcohols and aldehydes) were also found in typical proportions [10]. Vacuum-expansion yielded an essential oil impoverished in monoterpene alcohols, while monoterpene aldehydes and acetates remained unaltered.

The relative distribution of volatile compounds from the native mandarin peels was similar to those from the limonene chemotype of mandarins (Citrus reticulata Blanco group) [11], showing a high proportion of limonene $(\sim 95 \%)$ followed by $\beta$-myrcene $(\sim 2 \%)$ and sabinene $(\sim 1 \%)$, and having a very low $\gamma$-terpinene content. It must be noted that two monoterpene aldehydes (neral and geranial) and acetates of monoterpene alcohols were not detected. As in the three other citrus species, relative proportions of monoterpene alcohols (linalol, $\alpha$-terpineol, $\beta$-citronellol and nerol) were lowered by a factor of 2 to 3 in the oils produced by vacuum-expansion. An aliphatic aldehyde, decanal, was $\times 4$ concentrated in this oil. Sesquiterpene aldehydes ( $\alpha$ - and $\beta$-sinensal) were lowered by a factor of 3 .

The relative distribution of volatile compounds from the native grapefruit peels was typical [10, 12] exhibiting a high limonene 
Table II.

Relative percentage of volatile components in essential oils from lemon, sweet orange, mandarin and grapefruit native and vaccuum-expanded peels.

\begin{tabular}{|c|c|c|c|c|c|c|c|c|c|c|}
\hline \multirow[t]{2}{*}{ Compound } & \multicolumn{2}{|c|}{ Linear retention index } & \multicolumn{2}{|c|}{ Lemon } & \multicolumn{2}{|c|}{ Sweet orange } & \multicolumn{2}{|c|}{ Mandarin } & \multicolumn{2}{|c|}{ Grapefruit } \\
\hline & on DB-Wax & on DB-1 & $\begin{array}{l}\text { native } \\
\text { oil }\end{array}$ & $\begin{array}{l}\text { ve essential } \\
\text { oil }\end{array}$ & $\begin{array}{c}\text { native } \\
\text { oil }\end{array}$ & $\begin{array}{l}\text { ve essential } \\
\text { oil }\end{array}$ & $\begin{array}{c}\text { native } \\
\text { oil }\end{array}$ & $\begin{array}{c}\text { ve essential } \\
\text { oil }\end{array}$ & $\begin{array}{c}\text { native } \\
\text { oil }\end{array}$ & $\begin{array}{l}\text { ve essential } \\
\text { oil }\end{array}$ \\
\hline$\alpha$-Pinene & 1028 & 918 & 1.53 & 1.63 & 0.50 & 0.50 & 0.51 & 0.18 & 0.48 & 0.49 \\
\hline$\alpha$-Thujene & 1032 & 923 & 0.33 & 0.41 & 0.01 & 0.01 & 0.01 & 0.01 & 0.01 & $n d^{5}$ \\
\hline Camphene & 1066 & 934 & 0.05 & 0.05 & 0.01 & 0.01 & nd & nd & 0.01 & nd \\
\hline Hexanal & 1083 & 780 & nd & nd & 0.04 & nd & 0.01 & nd & 0.05 & nd \\
\hline$\beta$-Pinene & 1106 & 960 & 8.97 & 10.77 & 0.02 & 0.04 & 0.06 & 0.18 & 0.03 & 0.06 \\
\hline Sabinene & 1119 & 960 & 1.52 & 1.78 & 0.35 & 0.46 & 1.13 & 0.28 & 0.28 & 0.30 \\
\hline$\delta$-3-Carene & 1139 & 996 & nd & nd & 0.64 & 0.44 & nd & nd & nd & nd \\
\hline$\beta$-Myrcene & 1163 & 976 & 1.45 & 1.68 & 1.91 & 2.00 & 1.76 & 1.50 & 1.79 & 1.91 \\
\hline$\alpha$-Terpinene & 1174 & 998 & 0.17 & 0.22 & nd & nd & nd & nd & nd & nd \\
\hline Limonene & 1198 & 1022 & 66.23 & 70.30 & 94.41 & 95.32 & 94.59 & 95.70 & 94.55 & 95.27 \\
\hline$\beta$-Phellandrene & 1201 & 1009 & 0.28 & 0.28 & nd & nd & nd & nd & nd & nd \\
\hline 1,8-Cineole & 1203 & 1010 & 0.02 & 0.02 & nd & nd & nd & nd & nd & nd \\
\hline$(E)$-2-Hexenal & 1211 & 824 & 0.01 & nd & 0.02 & nd & 0.03 & nd & 0.06 & nd \\
\hline (Z)- $\beta$-Ocimene & 1232 & 1023 & 0.06 & 0.05 & 0.01 & nd & 0.01 & 0.01 & 0.01 & 0.01 \\
\hline$\gamma$-Terpinene & 1241 & 1045 & 8.07 & 8.85 & 0.01 & 0.02 & 0.01 & 0.24 & 0.05 & 0.05 \\
\hline$(E)$ - $\beta$-Ocimene & 1247 & 1038 & 0.09 & 0.02 & 0.03 & 0.03 & 0.07 & 0.05 & 0.08 & 0.16 \\
\hline$p$-Cymene & 261 & 1001 & 0.07 & 0.09 & nd & nd & nd & 0.01 & 0.01 & 0.01 \\
\hline$\alpha$-Terpinolene & 1274 & 1072 & 0.38 & 0.39 & 0.13 & 0.08 & 0.04 & 0.03 & 0.02 & 0.01 \\
\hline Octanal & 1282 & 985 & 0.02 & 0.05 & 0.10 & 0.15 & 0.05 & 0.05 & 0.17 & 0.35 \\
\hline Nonanal & 1384 & 1077 & 0.07 & 0.07 & 0.02 & 0.03 & 0.01 & 0.01 & 0.04 & 0.05 \\
\hline cis-Sabinenehydrate & 1460 & - & 0.07 & 0.01 & 0.02 & nd & 0.01 & nd & nd & nd \\
\hline Citronellal & 1467 & 1128 & 0.10 & 0.07 & 0.06 & 0.04 & 0.07 & 0.10 & 0.08 & 0.06 \\
\hline Decanal & 1486 & 1182 & 0.04 & 0.03 & 0.15 & 0.16 & 0.18 & 0.46 & 0.31 & 0.18 \\
\hline Isopinocamphone & 1523 & - & 0.01 & nd & 0.02 & 0.02 & 0.04 & 0.07 & 0.09 & 0.11 \\
\hline$p$-Menth-2-en-1-one & 1542 & - & 0.12 & 0.09 & nd & nd & nd & nd & 0.01 & nd \\
\hline Linalool & 1544 & 1085 & 0.26 & nd & 0.38 & 0.18 & 0.35 & 0.09 & 0.12 & 0.05 \\
\hline cis- $\alpha$-Bergamotene & 1556 & 1431 & 0.08 & 0.01 & 0.07 & 0.02 & 0.05 & 0.03 & 0.10 & 0.15 \\
\hline trans- $\alpha$-Bergamotene & 1571 & 1417 & 0.52 & 0.24 & 0.02 & 0.01 & 0.03 & 0.18 & 0.04 & nd \\
\hline$\beta$-Caryophyllene & 1576 & 1393 & 0.33 & 0.15 & 0.04 & 0.05 & 0.10 & 0.09 & 0.30 & 0.38 \\
\hline Terpinen-4-ol & 1590 & 1160 & 0.13 & 0.02 & nd & 0.01 & 0.01 & nd & nd & nd \\
\hline$\beta$-Santalol & 1633 & - & 0.02 & 0.01 & nd & nd & nd & nd & nd & nd \\
\hline$\alpha$-Humulene & 1648 & 1424 & 0.03 & 0.02 & 0.01 & 0.01 & 0.02 & 0.03 & 0.05 & 0.04 \\
\hline Citronellyl acetate & 1653 & 1333 & 0.03 & 0.02 & nd & nd & nd & nd & nd & nd \\
\hline (Z)- $\beta$-Farnesene & 1658 & 1209 & 0.11 & 0.02 & 0.01 & nd & nd & nd & 0.03 & 0.04 \\
\hline Neral & 1665 & 1208 & 1.13 & 0.58 & 0.05 & 0.05 & nd & nd & 0.05 & 0.03 \\
\hline$\alpha$-Terpineol & 1687 & 1170 & 0.63 & 0.10 & 0.07 & 0.03 & 0.09 & 0.01 & 0.07 & 0.02 \\
\hline Dodecanal & 1695 & 1384 & 0.03 & 0.01 & 0.04 & 0.02 & 0.08 & 0.06 & 0.08 & 0.02 \\
\hline Valencene & 1696 & 1240 & 0.09 & 0.04 & 0.39 & 0.12 & nd & nd & 0.02 & nd \\
\hline$\beta$-Bisabolene & 1712 & 1500 & 0.48 & nd & nd & nd & 0.04 & 0.23 & 0.05 & nd \\
\hline Neryl acetate & 1713 & 1341 & 0.16 & nd & 0.01 & 0.01 & nd & nd & 0.05 & 0.03 \\
\hline
\end{tabular}




\begin{tabular}{|c|c|c|c|c|c|c|c|c|c|c|}
\hline \multirow[t]{2}{*}{ Compound } & \multicolumn{2}{|c|}{ Linear retention index } & \multicolumn{2}{|c|}{ Lemon } & \multicolumn{2}{|c|}{ Sweet orange } & \multicolumn{2}{|c|}{ Mandarin } & \multicolumn{2}{|c|}{ Grapefruit } \\
\hline & on DB-Wax & on $\mathrm{DB}-1$ & $\begin{array}{c}\text { native } \\
\text { oil }\end{array}$ & $\begin{array}{l}\text { ve essential } \\
\text { oil }\end{array}$ & $\begin{array}{l}\text { native } \\
\text { oil }\end{array}$ & $\begin{array}{l}\text { ve essential } \\
\text { oil }\end{array}$ & $\begin{array}{l}\text { native } \\
\text { oil }\end{array}$ & $\begin{array}{l}\text { ve essential } \\
\text { oil }\end{array}$ & $\begin{array}{c}\text { native } \\
\text { oil }\end{array}$ & $\begin{array}{c}\text { ve essential } \\
\text { oil }\end{array}$ \\
\hline Geranial & 1716 & 1240 & 2.90 & 1.66 & 0.13 & 0.09 & nd & nd & 0.15 & 0.04 \\
\hline$\delta$-Cadinene & 1739 & 1516 & nd & nd & 0.05 & 0.03 & 0.11 & 0.15 & 0.17 & nd \\
\hline Geranyl acetate & 1747 & 1357 & 0.32 & 0.14 & 0.02 & 0.01 & nd & nd & 0.07 & 0.05 \\
\hline$\beta$-Citronellol & 1763 & 1208 & 0.19 & 0.01 & 0.04 & nd & 0.05 & 0.02 & 0.03 & 0.02 \\
\hline Nerol & 1793 & 1208 & 1.07 & 0.02 & 0.05 & 0.01 & 0.01 & 0.02 & 0.02 & 0.01 \\
\hline Geraniol & 1843 & 1240 & 1.70 & 0.02 & 0.07 & 0.01 & 0.02 & 0.02 & 0.05 & 0.02 \\
\hline (E)-Nerolidol & 1013 & 1547 & 0.03 & 0.01 & 0.01 & nd & 0.02 & 0.02 & 0.02 & 0.01 \\
\hline$\gamma$-Eudesmol & 2151 & - & 0.03 & 0.01 & nd & nd & nd & nd & nd & nd \\
\hline$\alpha$-Bisabolol & 2200 & 1662 & 0.05 & 0.01 & nd & nd & nd & nd & nd & nd \\
\hline$\beta$-Sinensal & 2201 & 1673 & nd & nd & 0.01 & 0.02 & 0.11 & 0.04 & 0.04 & 0.01 \\
\hline$\alpha$-Sinensal & 2272 & 1726 & nd & nd & 0.01 & nd & 0.33 & 0.16 & 0.05 & nd \\
\hline Nootkatone & 2280 & 1802 & 0.01 & 0.05 & 0.05 & 0.02 & nd & nd & 0.33 & 0.05 \\
\hline
\end{tabular}

ve: vacuum-expanded; nd: not detected.

content ( 95\%) and decreasing proportions of $\beta$-myrcene $(\sim 1.9 \%), \alpha$-pinene $(\sim 0.5 \%)$ and sabinene $(\sim 0.3 \%)$. Linalool and $\alpha$-terpineol were the major monoterpene alcohols $(\sim 0.1 \%$ to $0.15 \%)$ of the native peel oil, and their relative levels were divided by a factor of 2 after vacuum-expansion like other monoterpenols, $\beta$-citronellol, nerol and geraniol. Finally, the concentration of nootkatone, a typical grapefruit volatile component [13], decreased from (0.3 to $0.05) \%$ after vacuum-expansion (table II).

\section{Conclusion}

The flash vacuum-expansion process, when applied to peels from different Citrus species (lemon, sweet orange, mandarin and grapefruit), afforded essential oils in yields equivalent to those attainable by the F.M.C. process. Oils were relatively enriched in limonene with a correlative impoverishment in oxygenated compounds (monoter- pene alcohols, aldehydes and esters) while aliphatic aldehydes either remained stable or proportionally increased.

\section{References}

[1] Pruthi J.S., Parekh C.M., Lal G., An integrated process for the recovery of essential oil and pectin from mandarin orange waste, Food Sci. (1961) 372-378.

[2] Rouse A.H., Crandall P.G., Nitric acid extraction of pectin from citrus peel, Proc. Fla. State Hortic. Soc. 89 (1976) 166-168.

[3] Braddock R.J., Cadwallader K.R., Citrus byproducts manufacture for food use, Food Technol. 46 (1992) 105-110.

[4] Anonymous, Citrus systems. Citrus extractors, FMC FoodTech, Citrus Systems, Lakeland (Fla) USA, 2001, http://www. fmcfoodtech.com/ourgroup/citrus/extrac1.htm

[5] Dugo G., The composition of the volatile fraction of the Italian citrus essential oils, Perfum. Flavor 19 (1994) 29-51. 
P. Brat et al.

[6] Ageron D., Escudier J.L., Abbal P., Moutounet M., Prétraitement des raisins par flash-détente sous vide poussé, Rev. Fr. Oenol. 153 (1995) 50-54.

[7] Cogat P.O., Procédé et matériel d'extraction, concentration, classement de composés volatils, entraînables, sapides et/ou solubles en mélange hydroalcoolique à partir de solides végétaux et animaux, Patent, no 9205669, Institut National de la Propriété Industrielle, Paris, France, 1992.

[8] Brat P., Brillouet J.-M., Reynes M., Cogat P.O., Ollé D., Free volatile components of passion fruit puree obtained by flash vacuumexpansion, J. Agr. Food Chem. 48 (2000) 6210-6214.

[9] Jennings W., Shibamoto T., Compounds and their retention indices, in: Jennings W., Shibamoto T. (Eds), Qualitative analysis of flavor and fragrance volatiles by glass capillary gas chromatography, Acad. Press, New York, USA, 1980.

[10] Boelens M.H., A critical review on the chemical composition of citrus oils, Perfum. Flavor 16 (1991) 17-34.

[11] Lota M.-L., de Rocca Serra D., Tomi F., Casanova J., Chemical variability of peel and leaf essential oils of mandarins from Citrus reticulata Blanco, Biochem. Syst. Ecol. 28 (2000) 61-78.

[12] Coleman R.L., Lund E.D., Shaw P.E., Analysis of grapefruit essence and aroma oils, J. Agr. Food Chem. 20 (1972) 100-103.

[13] Sawamura M., Kuriyama T., Quantitative determination of volatile constituents in the pummelo (Citrus grandis Osbeck forma Tosa-buntan), J. Agr. Food Chem. 36 (1988) 567-569.

\section{Aceites esenciales obtenidos por expansión súbita al vacío de cortezas de limones, naranjas, mandarinas y toronjas.}

Resumen - Introducción. Los aceites esenciales tienen una importancia económica que va en aumento dentro de la industria de subproductos de cítricos. La técnica de la expansión súbita (flash vacuum-expansion), un proceso que provoca la desintegración de tejidos vegetales, se ha aplicado a la extracción de aceites esenciales de cuatro especies de Citrus. Material y métodos. La técnica de expansión súbita al vacío (vapor caliente seguido de la introducción rápida en un recipiente al vacío) se aplicó a cortezas de limones, naranjas, mandarinas y toronjas. Se recuperaron los aceites esenciales mediante un condensador y, luego, se separaron por centrifugación. Los compuestos volátiles de aceite se separaron e identificaron, seguidamente, mediante espectrometría por cromatografía gas-líquido con columna capilar. Resultados y discusión. Los rendimientos en aceites esenciales de las cortezas fueron de $(2,41,1,43,0,64$ y $0,73 \mathrm{~kg}) \times \mathrm{t}^{-1}$ de fruta para el limón, naranja, mandarina y toronja, respectivamente. Los aceites fueron enriquecidos con limoneno y otros monoterpenos, mientras que se empobrecieron concentraciones relativas de alcoholes monoterpénicos (linalool, $\alpha$-terpineol, $\beta$-citronellol, nerol, geraniol) y de aldehídos (neral, geranial) con respecto a los compuestos volátiles de las cortezas naturales. Conclusión. La técnica de la expansión súbita al vacío ha permitido la extracción de aceites esenciales de cortezas de agrios con rendimientos semejantes a los que se obtienen mediante el procedimiento de la Food Machinery Corporation (F.M.C.). Los aceites fueron enriquecidos con hidrocarburos de monoterpeno y correlativamente empobrecidos en componentes volátiles oxigenados.

Citrus / sector agroindustrial / métodos / extracción / aceites esenciales / extractos vegetales / piel (vegetal) 